\title{
LTERATION OF THE ETHNIC DIVERSITY AND ETHNIC 1 SEGREGATION INDEX IN LATVIA DURING THE FIRST AND SECOND INDEPENDENCE PERIODS
}

\section{Ádám Németh, Guntis Šolks}

Ádám, Németh: University of Pécs, Institute of Geography, Dept. of Human Geography and Urban Studies/Hungary, E-mail: nemethadam@gamma.ttk.pte.hu Guntis, Šolks: University of Latvia, Faculty of Geography and Earth Sciences / Latvia, E-mail: guntis.solks@inbox.lv

\section{Acknowledgments}

This paper has been presented at the Third International Conference on Nordic and Baltic Studies: European networks: the Balkans, Scandinavia and the Baltic world in a time of economic and ideological crisis hosted by the Romanian Association for Baltic and Nordic Studies, Târgoviste, May 25-27, 2012.

\begin{abstract}
:
It is a well-known fact that the Baltic area is traditionally one of the most diverse regions of Europe in terms of ethnic concerns; we can observe in many settlements that four or even five religions have their own churches, cemeteries and at least as many ethnic groups are having their schools etc. Regarding geography literature, no generally accepted method has been applied yet to measure the population's diversity and spatial segregation; in most cases only the number and ratio of ethnic groups were described. This research paper proposes a different approach: the adaptation of the so-called Simpson's Diversity Index, based on probability theory and originally used by ecologists to measure biodiversity, to human geography. The study seeks the answers to: where, when, why and how has the Ethnic Diversity and Ethnic Segregation Index changed in Latvia during the first and second independence periods? What kind of spatial patterns are possible to observe on the basis of the transformation? The enormous data is processed by modern GIS software products and projected on thematic maps.
\end{abstract}




\section{Rezumat:}

Este binecunoscut faptul că arealul Baltic reprezintă în mod tradițional una dintre cele mai diverse regiuni ale Europei în materie de provocări etnice; putem observa în numeroase așezări că nu mai puțin de patru sau chiar cinci religii își au propriile biserici, cimitire și cel puțin tot atâtea grupuri etnice au propriile școli etc. În ceea ce privește literatura științifică geografică, nu s-a reușit încă aplicarea unei metode general acceptate capabile să măsoare diversitatea populației și segregarea spațială; în cele mai multe cazuri sunt descrise doar numărul și proporția minorităților etnice. Această lucrare științifică își propune o abordare diferită: adaptarea așa-numitului Indice Simpson al Diversității - bazat pe teoria probabilității și folosit inițial de ecologiști pentru a măsura biodiversitatea - la domeniul geografiei umane. Studiul caută un răspuns la întrebările unde, când, de ce şi cum s-a schimbat Indicele Diversității și Segregării Etnice în Letonia în timpul primei și al celei de-a doua perioade a independenței? Ce fel de trăsături spațiale sunt posibile a fi observate pe baza acestei transformări? Datele foarte bogate sunt procesare prin produse software GIS moderne și proiectate pe mape tematice.

Keywords: Latvia, ethnic, diversity, segregation, isolation, 20th century

\section{Introduction}

The Baltic region plays the role of a special macro-region in our continent: it constitutes a natural bridge (and sometimes a wall and fortress) between Northern and Central and also between Western and Eastern Europe. For hundreds of years this peculiar geostrategic position has been determining the everyday life of the area's inhabitants, thus it is not accidental that one of the oldest and most classical buffer zones of our continent is located here. By proving that there are no sharp, straight linelike borders in the geographic space, it is an excellent example of the definition of ethnic contact zone as well: during the $19^{\text {th }}-20^{\text {th }}$ centuries an exceptional mixture of nations (Estonians, Latvians, Lithuanians, Russians, Belarusians, Poles, Germans, Swedes, Jews, Tatars, etc.) lived in this area. In spite of the small size of the territory and the relative small numbers of the residents of Latvia, there are significant regional differences in ethnic structure as well as in the degree of ethnic diversity and/or segregation. 


\section{Aims and methods}

Homogeneous, heterogeneous, mixed, segregated: in everyday and academic life these notions are used so often that we do not even wonder if we can define them at all and whether we have an idea about when a particular community can be considered homogeneous or heterogeneous. If we cannot attach objective parameters to these expressions, they will surely remain vague, elusive abstractions. The authors believe that besides the traditional descriptive methods there is a strong need for additional indices which clarify the above mentioned expressions. This paper does not aim to fully analyse the metamorphosis of Latvia's ethnic structure during the 20th century; what our study attempts to answer are:

How can we define ethnic diversity and ethnic segregation?

Where, when, why and how has the EDI and ESI evolved in Latvia during the first and second independence periods and what kind of general trends and spatial patterns can be observed as the result of transformation?

\subsection{Ethnic Diversity Index (EDI)}

Regarding geography literature, no generally accepted method has been applied yet to measure the population's diversity; in most cases only the number and ratio of the ethnic groups were described. This research paper proposes a fundamentally different approach: the adaptation of the so-called Simpson's Diversity Index (Simpson 1949), based on probability theory and originally used by ecologists to measure biodiversity, to human geography. A number of similar indicators have been developed internationally, for example: Greenberg 1956; Meyer \& Overberg 2001; Ray 2008. Its extensive use has recently begun in Central Europe by Péter Bajmócy and Péter Reményi ${ }^{1}$. Although a number of similar indicators have been developed internationally, in case of Latvia they were rarely applied previously; e.g. Pēteris Zvidrinš̌ and Ilmārs Mežs used similar indexes

\footnotetext{
1Péter Bajmócy, 'Magyarország népességének etnikai és vallási diverzitása 1910-ben és 2001ben,' in Táj, környezet és társadalom, eds. Kiss, A. et al. (Szeged: SZTE Éghajlattani és Tájföldrajzi Tanszékés SZTE Természeti Földrajzi és Geoinformatikai Tanszék, 2006), 57-68; Idem, Általános etnikai és vallásföldrajz (Szeged: JATE Press, 2009), 65-72; Péter Reményi, 'Etnikai homogenizáció a volt Jugoszláviában,' in Magyarországés a Balkán - Balkánfüzetek, Különszám I, ed. M. Császár, Zs. (Pécs, 2009), 122-129.
} 
earlier, but they analysed only national level data ${ }^{2}$. The probability theory, which is based on a mathematical method, shows the likelihood of an event when two arbitrarily meeting inhabitants of an area belong to different ethnic groups. The values can vary between 0 and 1 , where 0.00 means a completely homogeneous population and 1.00 refers to a completely mixed population, and each member of the community belongs to a different nationality (Figure 1). The index is calculated as follows:

$$
E D I=\frac{L \times(L-1) / 2-\sum_{i=l}^{n} e i \times(e i-1) / 2}{L \times(L-1) / 2}
$$

where:

L: total population of the municipality

e1, e2, ..., en: the population count of certain ethnic groups

EDI: Ethnic Diversity Index

It is important to emphasize that while in nature the change of biodiversity can be interpreted as a qualitative change (e.g. the value of biodiversity decreases due to environmental pollution), in human geography it can only be treated as a strictly quantitative category. The formula is further complicated because while in nature a certain organism can be put into a single category, identity in modern societies is the result of one's own decision. Therefore ethnic identity is not static but rather it is a category that can be changed by family, political reasons etc. In order to ... of the process we have to take into account natural growth, migration and statistically elusive factors (e.g. assimilation, identity) too.

2Pēteris Zvidrinš̌ and Ilmārs Mežs, Latvieši. Statistiski demogrāfisks portretējums (Riga: Zinātne, 1992): "etniskā mozaiskuma indekss"; Ilmārs Mežs, 'The Ethno-Demographic Status of the Baltic States,' GeoJournal, vol. 33, 1 (1994): 17: “etniskās vides viendabības indekss.

Joseph H. Greenberg, 'The Measurement of Linguistic Diversity', Language, Vol. 32, 1 (January - March 1956): 109-115; P. Meyer and P. Overberg, 'Updating the USA TODAY Diversity Index' (2001) available at: http://www.unc.edu/ pmeyer/carstat/tools.html, accessed at 28 July 2011; B. Ray, 'A Description of the Ethnic Segregation/Mixing within Major Canadian Metropolitan Areas Project,' (University of Ottawa, 23 p.), available at: http://www.cic.gc.ca/english/pdf/research-stats/ethnic-segregation.pdf, 15 etc.

But probability theory is also often used in order to measure e.g. ethnic segregation or the probability of having a partner from the same/other ethnic group: M. Strömgren, 'Pre-Hire Factors and Workplace Ethnic Segregation,' IZA Discussion Paper, April 2011, No. 5622; M. van Ham and T. Tammaru, 'Ethnic Minority - Majority Unions in Estonia,' European Journal of Population, Vol. 27, 3 (August 2011): 313-335, available at: http://www.ncbi.nlm.nih.gov/pmc/articles/PMC3163815. 
Despite the difficulities, however, we must see that as it is basically a mathematical method, the Ethnic Diversity Index is ideal for ethnic studies too. The authors regard EDI as a necessary "complementary" quantitative method which principally throws new light upon traditional research methods in ethnic geography. Instead of using pie charts and tables the Ethnic Diversity Index expresses in an objective way - yielding an exact numerical value - the real value of diversity in terms of mathematics.

\subsection{Ethnic Segregation Index (ESI)}

The Ethnic Segregation Indexrepresents the degree of spatial segregation (isolation) or spatial dispersion of a particular ethnic group. Its value can vary between 0 and 100 where 0.0 shows the perfect mixing and 100.0 shows the perfect segregation (Figure 1). The index is calculated as follows ${ }^{3}$ :

$$
E S I=\frac{1}{2} \times \sum|A i-X i|
$$

where:

Ai: the rate of the ethnic group in percentage among all " $\mathrm{A}$ "-s in the " $\mathrm{i}$ " territorial unit,

$\mathrm{Xi}$ : the rate of all other ethnic groups $(X)$ among all " $\mathrm{X}$ "-s in the " $\mathrm{i}$ " territorial unit.

The use of EDI and ESI has at least two significant consequences for social sciences. Firstly, the above mentioned definitions can be standardized: with the same boundary conditions any areas in the world become comparable on the basis of ethnic diversity and segregation. Secondly, by the exact nature of the method, it will no longer depend on a personal judgment as to what extent they consider a community heterogeneous or homogeneous, mixed or segregated. In terms of numbers, there is no possibility to play a trick. This way we can somehow reduce the room of particular political and ideological interest groups who like to manipulate people with half-truths lacking concrete facts.

33ajmócy 2009, 65-72. 
Figure 1. Models for the EDI and ESI

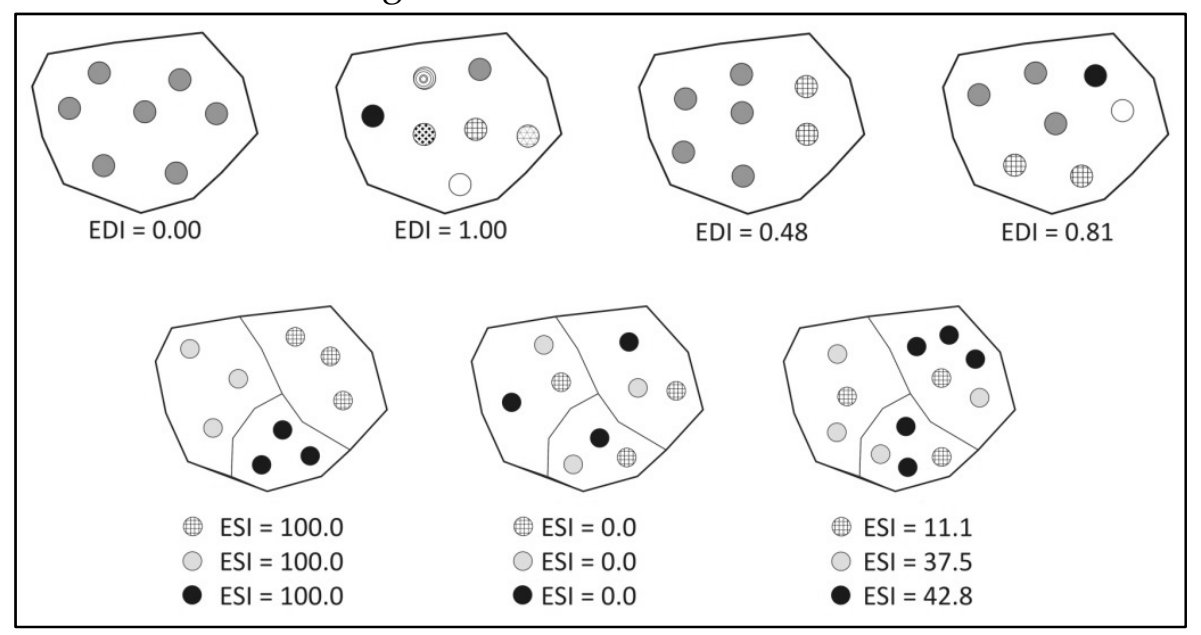

Edited by the authors

\subsection{Sources and GIS methods}

The data used in the study were taken from the printed and electronic documents of the Central Statistical Bureau of Latvia. The authors used municipality-scale national databases from 1925, 1935, 1989 and 2000, while district-scale data were available from the censuses in 1897, 1925, 1935, 1959, 1970, 1979, 1989, 2000 and from 2009. The calculation as well as illustration of the ethnic structure's territoriality was supported by ArcGIS 9.2 software product.

\section{Results - EDI at country level}

It is interesting in itself that although the superficial international media and general public often handle the Baltic region as a uniform territory, significant regional alterations can be observed concerning e.g. the transition of the ethnic diversity too. While the $20^{\text {th }}$ century led Lithuania on the road of ethnic-vernacular homogenisation (the diversity index decreased from 0.59 in 1897 to 0.28 in 2009), an opposite process took place in Estonia: the index increased from 0.18 to 0.48 . On the contrary, the EDI changed relatively slightly in Latvia: it increased from 0.51 in 1897 to 0.57 - however this was in 2009 one of the highest rates in whole Europe. We could find higher values only in Montenegro, in Bosnia and 
Herzegovina and in Switzerland4. According to the results of the latest census in 2011 EDI decreased to 0.54 .

The change in the Ethnic Diversity Index showed a characteristic wave during the $20^{\text {th }}$ century: its measure decreased until the World War II, then rose steadily until 1989 and then after the restored independence it showed a downward trend (Figure 2, Table 1).In the meanwhile the component parts of the society have been exchanged: the Jews and Germans have almost disappeared, but the number and ratio of the Russians, Belarusians, and Ukrainians have drastically increased. According to the aims of this study especially the data from the period 1925-1935 and 1989-2000 are relevant. It is very interesting that during the first and second independence period a very similar ethnic homogenization occurred in Latvia: the Ethnic Diversity Index decreased by 0.03 and by 0.04 .

Figure 2.Changes of the ethnic composition and the Ethnic Diversity Index of Latvia (1897-2009)

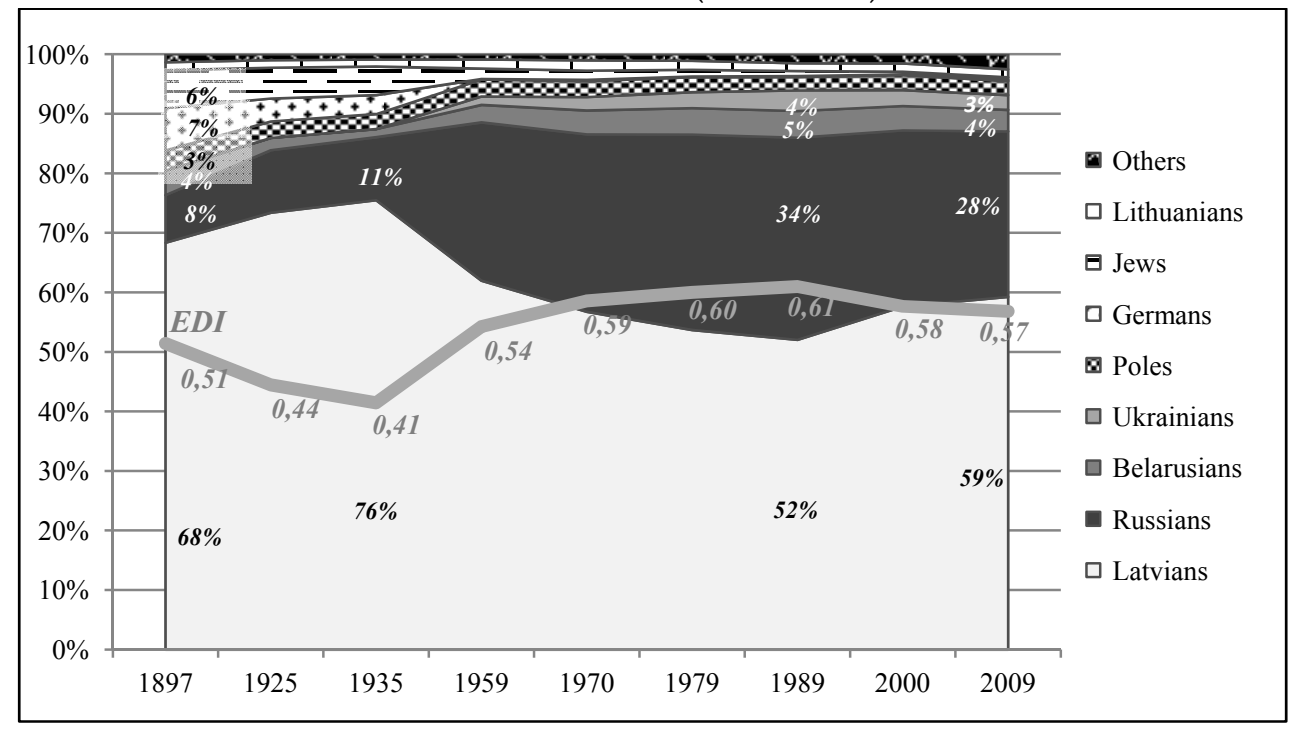

1897: data by mother tongue; 1925, 1935: with Abrene district Edited by the authors

4in virtue of the database: Bajmócy 2009, 91-108. 
Table 1. Population number by ethnicities in Latvia (1897-2009, in thousands)

\begin{tabular}{|c|c|c|c|c|c|c|c|c|c|c|}
\hline Year & 丞 & 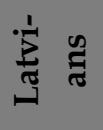 & $\begin{array}{l}\frac{1}{\infty} \\
\text { के } \\
\stackrel{\approx}{\approx}\end{array}$ & 龒 & $\begin{array}{l}\frac{1}{\pi} \\
\frac{\pi}{5} \\
\frac{\pi}{5}\end{array}$ & $\frac{\mathscr{e}}{0}$ & 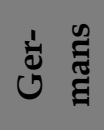 & $\stackrel{\infty}{\stackrel{\infty}{e}}$ & 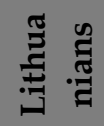 & $\frac{\mathscr{0}}{\tilde{d}}$ \\
\hline 1897 & 1,929 & 1,319 & 155 & 80 & $?$ & 65 & 137 & 123 & 26 & 26 \\
\hline 1925 & 1,845 & 1,354 & 194 & 38 & $?$ & 51 & 71 & 96 & 23 & 18 \\
\hline 1935 & 1,950 & 1,473 & 206 & 27 & $?$ & 49 & 62 & 93 & 23 & 17 \\
\hline 1959 & 2,093 & 1,298 & 556 & 62 & 29 & 60 & 2 & 37 & 32 & 18 \\
\hline 1970 & 2,364 & 1,342 & 705 & 95 & 53 & 63 & 5 & 37 & 41 & 24 \\
\hline 1979 & 2,503 & 1,344 & 821 & 112 & 67 & 63 & 3 & 28 & 38 & 27 \\
\hline 1989 & 2,667 & 1,388 & 906 & 120 & 92 & 60 & 4 & 23 & 35 & 40 \\
\hline 2000 & 2,377 & 1,371 & 703 & 97 & 64 & 60 & 3 & 10 & 33 & 36 \\
\hline 2009 & 2,261 & 1,340 & 629 & 82 & 56 & 53 & 5 & 10 & 30 & 57 \\
\hline
\end{tabular}

1897: data by mother tongue. 1925, 1935: with Abrene district

Edited by the authors

\section{Results - EDI at district level}

\subsection{First Independence Period. Analysed Period: 1925-1935}

The World War I and the following Latvian war of independence led to a serious demographic crisis in Latvia and changed the ethnic composition significantly, too. In 1925 with an approximately 20,000 fewer people lived in Latvia than at the end of the $19^{\text {th }}$ century. Only the Latvians' and Russians' number and proportion showed slight increase $(+35,000$ Latvian; +5.1 percentage points and $+39,000$ Russian; +2.5 percentage points), the total number and the proportion of the other minorities reduced significantly 5 . The number of the Latvians grew first of all due to the relatively high natural increase and the Latvian immigrants from the Soviet Union after the war; while the increase of the number of the Russians could be explained by the joining of the Russian-dominated Abrene district to Latvia. Since the frontline cut the country into two along the Daugava River until 1917, the World War I caused serious decline in the population number of the Belarusians, Poles and Germans as well (war

${ }^{5}$ estimated numbers, since 1897 census data referred to mother tongue 
casualties, emigration); however a notable part of the Germans returned after 1920 (Figure 3).

Figure 3. Changes of the population number of Latvia by ethnic groups (1897-1925* and 1925-1935)

*estimated numbers, since 1897 census data referred to mother tongue

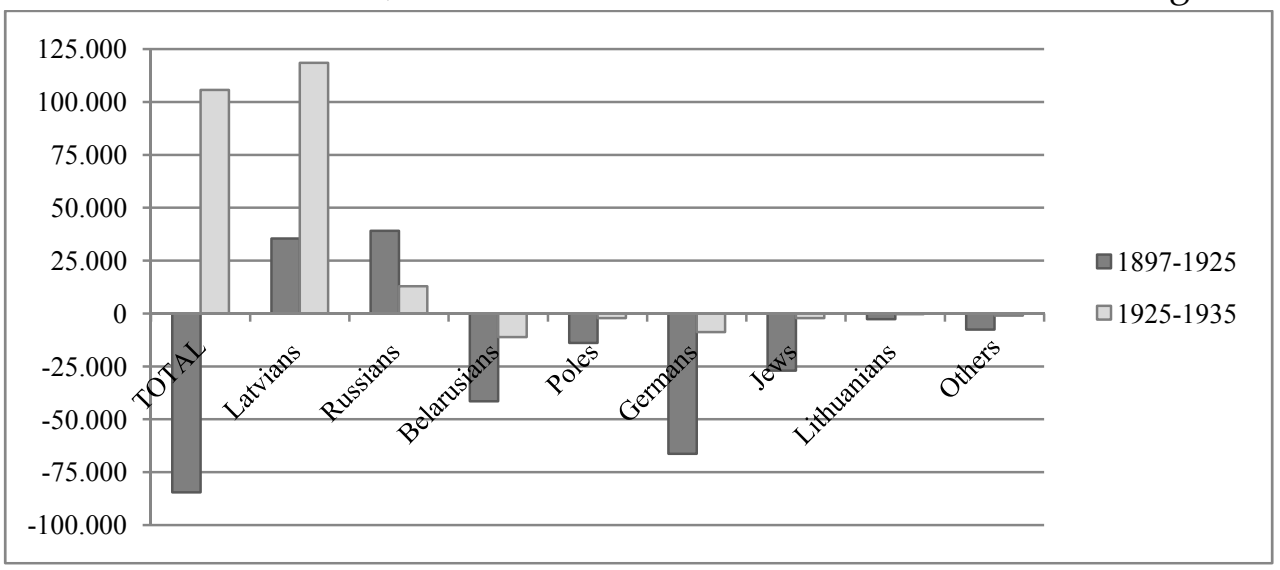

Edited by the authors

In $192573 \%$ of the population identified themselves as Latvian. They constituted an absolute majority in 18 and relative majority in one district, although there was a significant difference between rural and urban areas. Latvians, Lithuanians and Belarusians concentrated rather in the countryside, while Russians, Germans and Jews were more urbanized ethnic groups. Most of the administrative units had homogeneous, while five districts had relatively heterogeneous ethnic composition (Figure 4); all of them were located in East Latvia. Latgale was always the most typical example of the Baltic-Slavic ethnic contact zone ${ }^{6}$; little wonder that the most diverse district situated also there: Ilūkste district was probably the most

6 H. Strods, Latgales iedzīotāju etniskais sastāvs 1772-1959 (Riga: P. Stučkas Valsts Universitāte, Vēstures un Filozofijas Fakultāte, 1989). Furthermore the eponymous ethnic community has a strong regional identity, which is due to their Latgalian native language, which some linguists define as an own language not as only a dialect (E. Bojtár, Bevezetés a baltisztikába (Budapest: Osiris, 1997), 169-170), their Catholic religion originated from the Polish times, the manifestations of the Latgalian ethnic mentality in every-day life and the sense of detachment from the rest of Latvia (P. Zeile, 'Latgaliešu etno mentālitāte un kultūra,' ActaLatgalica, Daugavpils, 9 (1997): 281; A. Ivanov, 'Historiography as Framing and Support Factor of Ethnic Identity: the Case of Historiography of Latgale,' in Ethnicity. Politics of Recognition, ed. V. Volkov, Vol. 2. 1 (Daugavpils: 2010), 8-9. 
ethnically diverse area not only in the Baltic region but also in Europe $(0.76)$ !

Between 1925 and 1935 the population number of the country increased by ca. 105,000 people. Only the Latvians' (ca. +118,000) and Russians' (ca. $+13,000$ ) number increased again: the share of the former ones grew by 2.1 ; the latter ones by 0.1 percentage points. At the same time the summed proportion of the minorities dropped to $24.5 \%$ (Figure 3). The decline can be explained first and foremost by the emigration and assimilation: "about 50,000 former non-Latvians became Latvians by assimilation, most of them in Eastern Latvia". ${ }^{7}$ It is difficult to find out: was it a spontaneous or artificial process, anyhow the total population number of the minorities was definitely higher than the statistics show. Namely the 1935 census was carried out in the era of the Ulmanis regime when the family and workplace aspects could raise difficulties in the honest data provision. 8 The "statistical assimilation" was supported among others by the fact that the children born in ethnically mixed families - where one of the parents was Latvian - were automatically defined as Latvians in the course of the census in $1935 .{ }^{9}$

\footnotetext{
7 I. Mežs, Latvieši Latvijā. Etnodemogrāfisks apskats (Riga: Zinātne, Latvijas vēstures institūta, etnogrāfiskas nodaļa, 1994), 20.

${ }^{8}$ G. von Rauch, R. J. Misiunas, R. Taagepera, A balti államok története (Budapest: Osiris-

Századvég - 2000, 1994), 59

${ }_{9}$ P. Zvidrinsš and I. Vanovska, Latvieši. Statistiski demogräfisks portretējums (Riga: Zinātne, 1992), 28
} 
Figure 4. Ethnic composition and Ethnic Diversity Indexes by districts of Latvia in 1925 and 1935

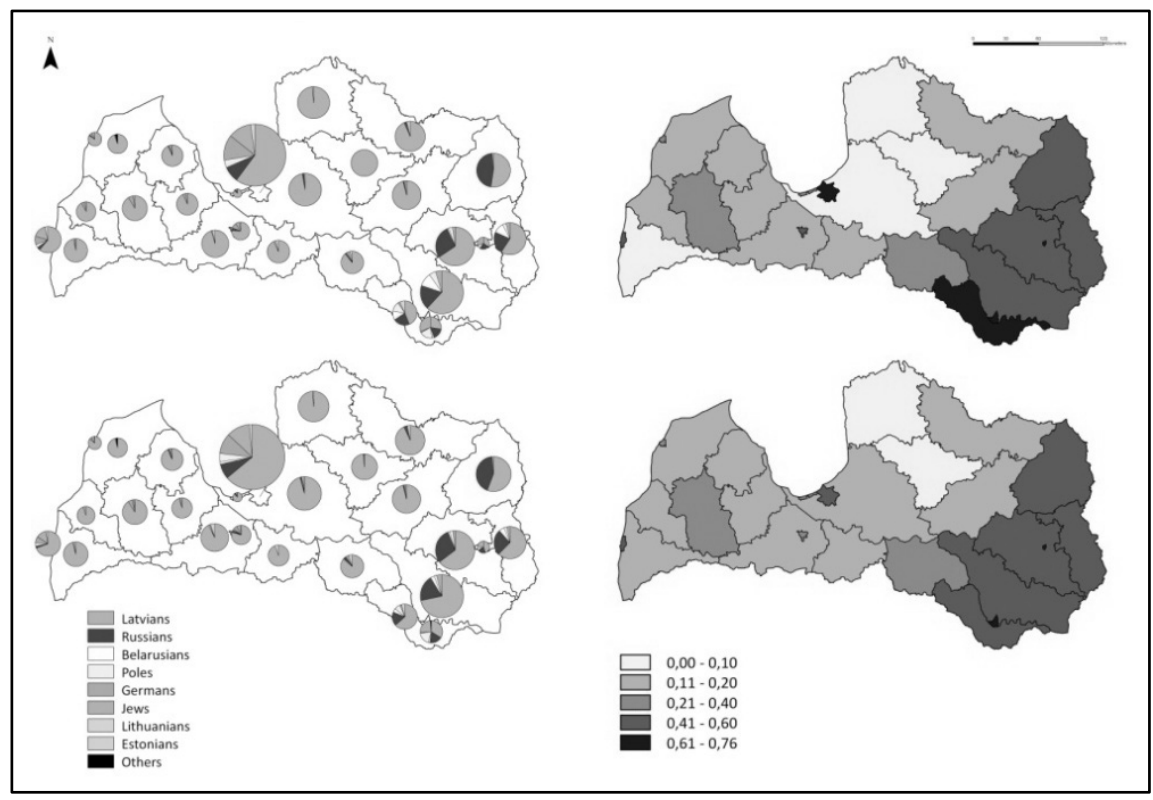

Edited by the authors

Figure 5. Change in proportion of Latvians and change of EDI by districts, 1925-1935

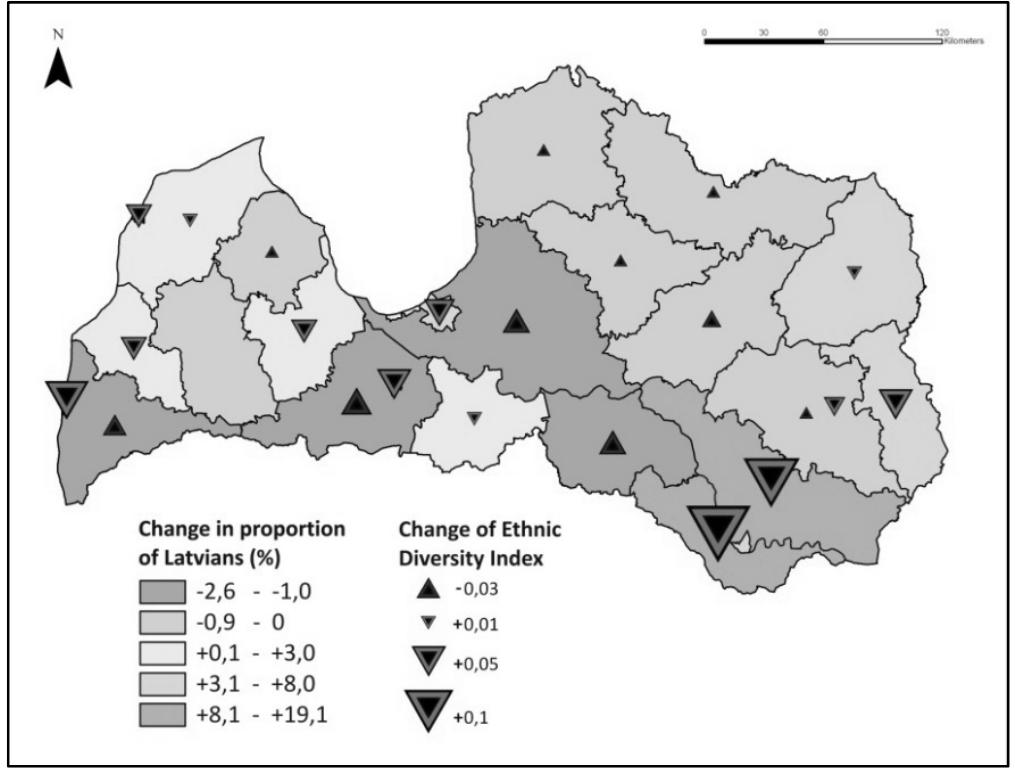

Edited by the authors 
Although the above mentioned processes resulted ethnic homogenization in Latvia, we can observe in the Figure 4 and 5 a reverse tendency: the tones did not change or even became darker between 1925 and 1935. This fact alludes unequivocally to heterogenization.

The increase of the EDI in Vidzeme and Zemgale can be explained by the slight decrease of the number and/or ratio of the Latvians in the countryside. E.g. between 1930 and 1935 - among the 19 districts - their number reduced in 4 and their proportion reduced in 14 units. The root cause of this phenomenon was the internal migration from rural to urban area; wherein principally the titular ethnic group took share. Furthermore due to the frequent shortage of the agrarian labour in certain districts, relatively numerous Polish, Russian and Belarusian casual labourers arrived from Latgale as well as from abroad. Thus e.g. in Vidzeme the proportion of the Slavs increased by 0.5 percentage points till 1935.10

But this is dwarfed by the reverse indices of Eastern Latvia: due to the above mentioned processes the proportion of Latvians grew by 3-19 percentage points in the districts of Latgale. This phenomenon produced notable decline in EDI. A similar homogenization took place in the bigger cities as well; the capital city Riga never before and since then had been as "Latvian" as in the interwar period. However, there were remarkable differences between the neighbourhoods, e.g. in Čiekurkalns, Jugla, Purvciems the Latvians acquired over $80 \%$, their share was below $40 \%$ in the "Moscow district" and in the old town.11

So at first glance it would seem: the most conspicuous change was ethnic heterogenization in that period; nevertheless it was typical mostly in the municipalities with low population number and with originally already low rate of ethnic diversity. Thus from the point of view of Latvia's aggregated EDI the dynamic ethnic homogenization of the towns and Riga abundantly overcompensated the moderate heterogenization of the rural area.

${ }^{10}$ CeturtātautasskaitīšanaLatvijā, 1935. 308

11Mežs 1994b, 40 


\subsection{Soviet Occupation Period}

The Baltic States have lost approximately $20 \%$ of their population in World War II which value is among the highest ones in Europe.12"At least 200,000 residents of Latvia (...) were either deported or killed by Nazis or Communists and another 200,000 Latvians sought refuge in the West" ${ }^{13}$ During this time the Germans (ca. 62,000 people) and Jews (ca. 93,000 people) virtually disappeared from the map of Latvia; in 1939 the former ones were "repatriated" to Germany, the latter ones were almost exterminated by the Nazi invaders. The Soviet Union occupied the Baltic States in 1944 and the republics could escape again from the "clamping arms" of Moscow around the collapse of the empire in 1991.These 47 years thanks to the permanent immigration flows once again changed the ethnic composition of the Baltic region. According to the calculations between 1945 and 1955 net migration in the Baltics reached almost one million persons ${ }^{14}$, while net migration in Latvia reached 525,000 persons between 1950 and 1990.

In 1989 , only $52 \%$ of the population of Soviet Latvia was ethnic Latvian and they were already a minority among the age groups between 20 and 45. Due to the differences in the level of urbanization (and indirectly in professional characteristics ${ }^{4}$ ) the titular ethnicity lived in a minority status in Riga and in the six regional centres: in Ventspils, Liepāja, Jūrmala, Jelgava, Rēzekne and Daugavpils. A similar situation emerged also in Latgale where before the restoration of independence out of the 420,000 people slightly over one-third identified themselves as Latvians. The colours of the maps of Figure 3 and 7 show a shocking change: the EDI in Latvia increased significantly almost everywhere. The only exception was Latgale where the rate of ethnic mixing remained nearly invariable. Here two opposite tendencies extinguished each other: the assimilation of nonRussian minorities into the Russian majority could have been so significant that it was able to compensate the general trend towards heterogenization.

It is a well-known fact that immigration primarily aimed at industrial centres and military bases; therefore the national structure including those municipalities and settlements has changed radically which

\footnotetext{
12Rauch,Misiunas andTaagepera1994, p. 219

13 I. Mežs, The Latvian Language in the Mirror of Statistics (Riga: Jāņasēta Map Publishers, 2005), 6-10

14 P. Zvidrinš, 'Changes of the Ethnic Composition in the Baltic States,' Nationalities Papers, vol. 22, 2 (1994): 367
} 
usually coupled with significant increase of EDI. Homogeneity remained characteristic for the northern and western part of Kurzeme and the central-eastern part of Latvia. The reasons of the remained homogenous Latvian environment were the following. These were mostly agricultural areas with low population density, with infrastructure in very pure condition and with a long distance from the capital and other industrial centres. Therefore, these settlements were not attractive at all for immigrants. Moreover, the consequence of mass deportations after WWII was relatively smaller in these territories. ${ }^{15}$

\subsection{Second Independence Period. Analysed Period: 1989-2009}

After the collapse of the Soviet Union the political transformation reversed all that previously characterized the Soviet occupation period. The natural increase was followed by decrease, mass immigration was replaced by emigration and the Russians have become from one moment to another a minority group of the three westward-looking reborn countries. Between 1989 and 2009 the population of the Baltic States decreased by about 956,000 due to the above-mentioned components. Since 1989 the total population number of Latvia decreased more than 400,000 (Figure 6); nearly half of this may be associated with the emigration of Russians. ${ }^{16} \mathrm{At}$ the beginning of the 1990s the industrial crisis and unemployment affected the Slavic dominated areas most sensitively (the overrepresented presence of Russians in the secondary sector is obvious), but every now and then due to the sometimes strict citizenship regulations many have returned to their mother country. ${ }^{17}$ The level of emigration reached the peak in 1992, when the former Soviet military forces and their family members left

\footnotetext{
15Mežs 1994a, 38

16Á. Németh'Von der Reichsmajorität zur marginalen Minderheit: die „Russische Frage” im sozialistischen und nachwendezeitlichen Baltikum,' in Minderheitendasein in Mittel- und Osteuropa - interdisziplinär betrachtet, Zs. Gerner \& L. Kupa (Hamburg: Verlag Dr. Kovač, Socialia - Studienreihe Soziologische Forschungsergebnisse, Band 133, 2011), 94.

${ }^{17} \mathrm{Sz}$. R. Győri, 'Autonómia a posztszovjet, európaiutódállamokban,' Kisebbségkutatás, Vol. 2 (2006), available

http://www.hhrf.org/kisebbsegkutatas/kk_2006_02/cikk.php?id=1366, accessed at 28 July 2011; G. Lagzi, Kisebbségikérdés, nemzetikisebbségekÉsztországban, LettországbanésLitvániában a rendszerváltástkövetôidőszakban

(Budapest:

EurópaiÖsszehasonlítóKisebbségkutatásokKözalapítvány, Múhelytanulmány 33, 2008)
} 
Latvia. ${ }^{18}$ The situation has changed for today: in parallel with the improvement of living standards the volume of emigration of Eastern Slavs has declined. In the meanwhile the fertility rate dropped from 2.04 in 1989 to 1.24 in 2000 and increased only just a little since then; it is lower than in most European countries. However fertility rates among Latvians are higher than the Russians' and other non-Latvian ethnicities; and similar tendency is typical of natural increase as well. ${ }^{19}$

Figure 6. Changes of the population number of Latvia by ethnic groups (1989-2000 and 2000-2009)

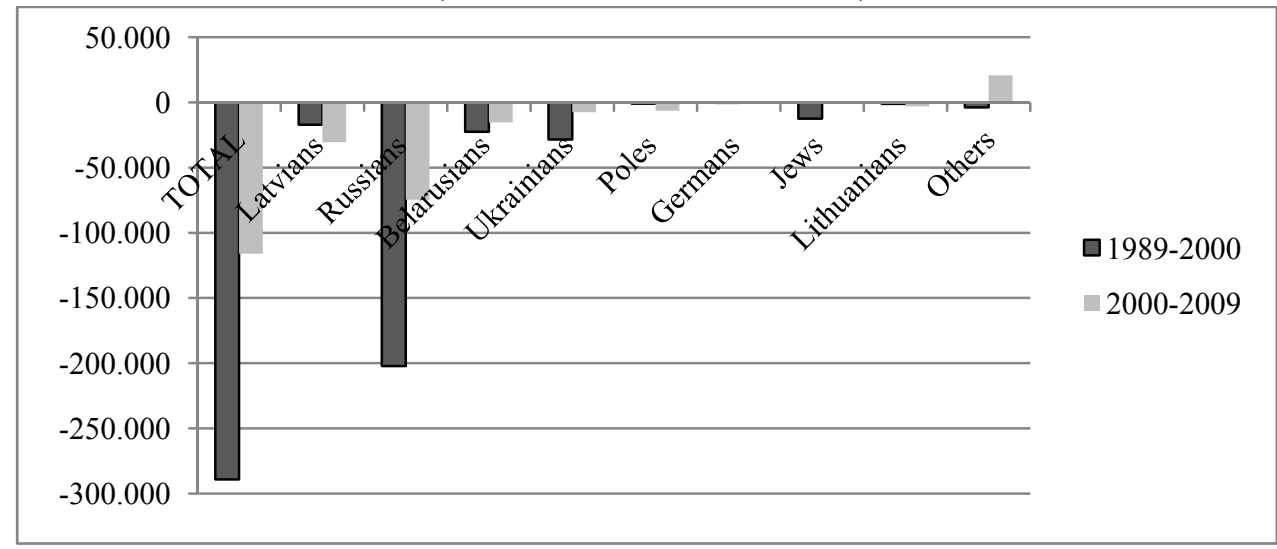

Edited by the authors

Of course the reversal of the demographic patterns has changed the ethnic composition as well as the Ethnic Diversity Index of Latvia. The proportion of the titular ethnicity increased from 52\% to 59\% between 1989 and 2009, while EDI decreased to 0.57. It is very interesting that during the first independence period and in the first decade of the second independence period a very similar ethnic homogenization occurred in Latvia: the EDI dropped in both cases by 0.03 .

However, it is important to take into account "soft" factors as well, first and foremost assimilation. Although compared to previous decades Latvians' capability of assimilation has become stronger, the bipolar

\footnotetext{
${ }^{18}$ E. Vìtolinsš and P. Zvidriņš, 'The Demographic Situation in Latvia at the Beginning of the $21^{\text {th }}$ Century,' in Demographic Development in Latvia, ed. V. Ivbulis (University of Latvia, Humanities and Social Sciences, 2(35)/2002), 27

19 This rate was e.g. in 2006 -2,7\%o among Latvians; -7,9\%o among Russians; -13,2\%o among Belarusians; -11,1\%o among Poles etc. (Latvijas Statistikas Gadagrāmata 2007, p. 130)
} 
(Latvian and Russian) "assimilation magnet" is still at work. A typical example of the former is that $80 \%$ of children born in mixed marriages are registered as Latvian. ${ }^{20}$ On the other hand, it has been shown in researches that among the non-Russian minorities only $8 \%$ use their own mother tongue at home, while most of them communicate rather in Russian or even Latvian. ${ }^{21}$

Looking for general regularities, in Latvia - as opposed to Estonia or Lithuania - a close mathematical relationship exists between the proportion of Latvians and the Ethnic Diversity Index: the low proportion of the eponymous ethnic group is coupled in almost all cases with a high-degree EDI. In other words: except for two or three units, one cannot speak about homogeneous Russian, homogeneous Polish etc. settlements. In a homogeneous environment mostly Latvian children grow up, however their number is low: in 2000 only $14 \%$ of the children of Latvia lived in homogeneous, while $47 \%$ of them in extremely heterogeneous (EDI > 0.6) municipalities. In the long run this situation can fundamentally influence the attitude of main ethnicities toward issues of cultural mixing.

Another conclusion that 'the greater migration loss resulted in generally a greater homogenization' is also true for the majority of the districts (Figure 7). However, we can see anomalies as well. The top left points (namely Riga, Rēzekne, Daugavpils cities) have lost $5-12 \%$ of their population but still the EDI values have increased, while on the right side the positive migration has been associated with homogenization. Suburbanization units such as Rigas, Ogres districts and Jürmala city belonged to the latter category: forming the members of an agglomeration ring around the capital city. But it must be remembered that these figures represent the summed net migration; included internal migration as well which is a very complex process in Latvia and it is difficult to establish a clear spatial trend. ${ }^{22}$

\footnotetext{
${ }^{20} \mathrm{~A}$. Bērziñš, 'Iedzīvotāju etniskā sastāva izmainu raksturojums,' in Demogrāfiskā attīstība Latvijā 21.gadsimta sākumā (Riga: Zinātne, No. 3(9), 2006), 136.

21 A. Aasland, Ethnicity and Poverty (Riga: Social Policy Research Series. Fafo Institute for Applied Social Science.Ministry of Welfare of the Republic of Latvia.UN Development Programme, 2000), 14.

${ }^{22}$ Krišjāne, Z. et al. (2004) 'Changing Patterns of Population Mobility in Latvia,' in Marking Latvia's Return to Europe, ed. Ā. Krauklis (Rīga: Ģeogrāfiski Raksti, XII. Latvijas Ģeogrāfijas biedrība, 2004), 65-73; Zaiga Krišjāne and Andris Bauls, 'Regional features of migraton in Latvia,' in Demographic situation : present and future, ed. P. Zvidrinș` (Riga: Research papers, Stratégiskās analizes komisija, 4 (8), 2006).
} 
Figure 7. Correspondence between the migration balance compared to the population number in 1989 (1989-2009, \%) and the changes of the EDI (1989-2009)

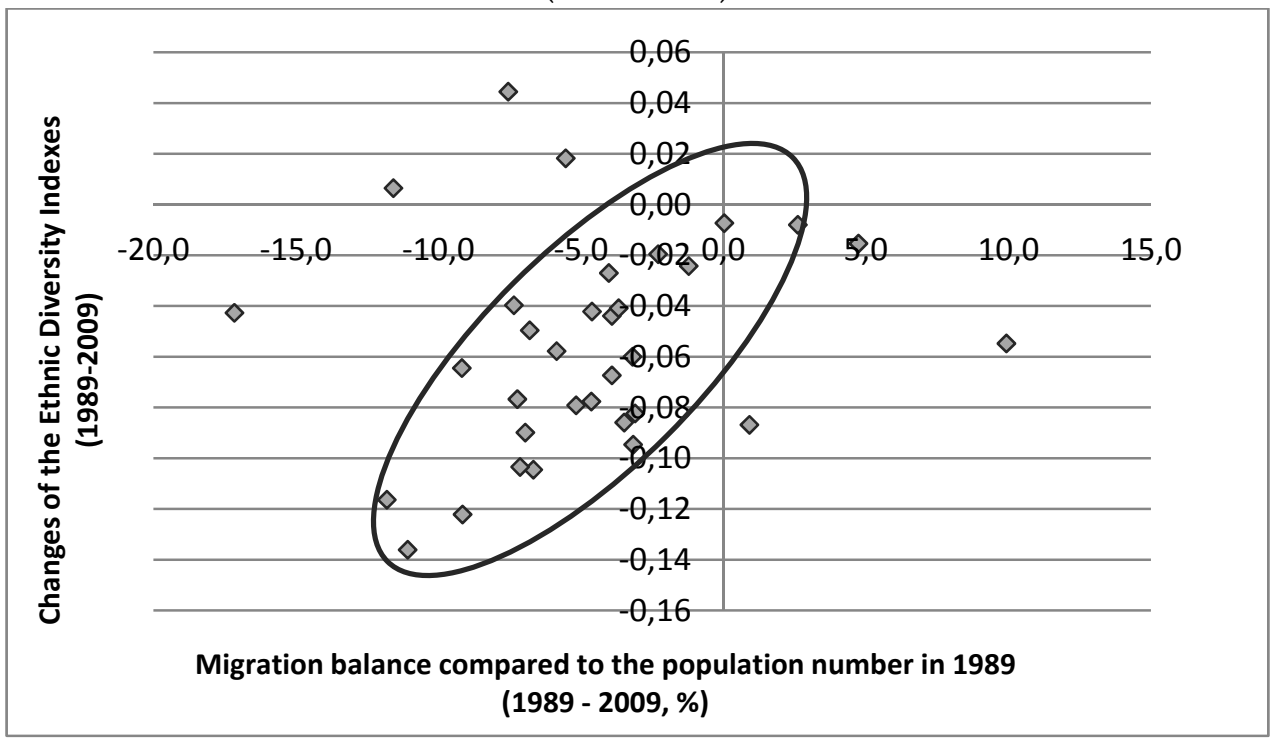

Edited by the authors

Concerning the spatial dimension of the EDI there have been no major changes since 1989, although the tones became lighter; this evidently refers to homogenization (Figure 8). Among the 27 administrative units in 24 cases homogenization, in 3 cases heterogenization took place. It is very interesting that in the administrative units of Latgale the EDI changed slightly after 1989 which can be explained by two processes. On the one hand, Latvians here formed the minority group whose weight moderately increased during the indicated demographic trends. On the other hand the emigration from Latgale was rather low because of the relatively small number of the non-citizens. ${ }^{23}$ Moreover, in three cities, in Riga, Daugavpils and Rèzekne ethnic heterogenization took place, is spite the fact that the share of Latvians grew in each of these settlements significantly (Figure 9). 
Figure 8. Ethnic composition and Ethnic Diversity Indexes by districts of Latvia in 1989 and 2009

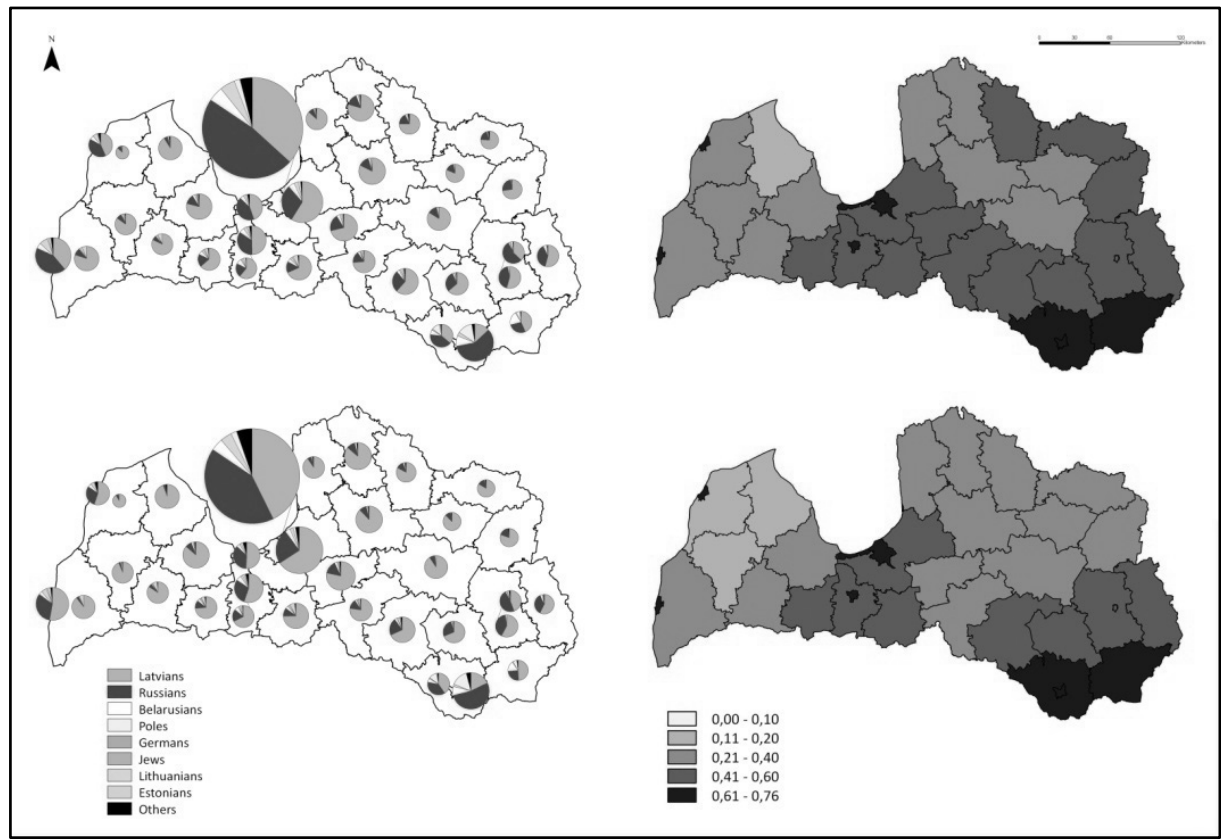

Edited by the authors

Figure 9.Change in proportion of Latvians and change of EDI 1989-2009

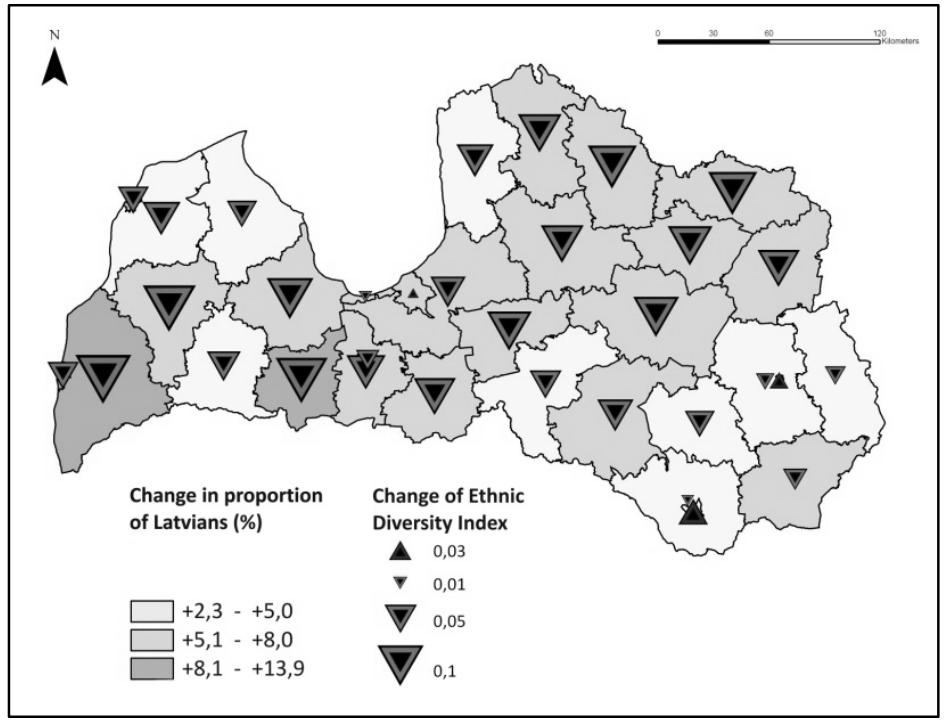

Edited by the authors 
This is where the new method, the application of EDI becomes reasonable. Most people perceive the period between 1989 and 1991 as a general political and economic landmark in Latvia's history that is automatically associated with the results of the 1989 census which - in terms of ethnicity - is supposed to be appraised as a historical nadir. From the viewpoint of the rate of ethnic mixing the "magical" year of 1989 is only a mental boundary since in many settlements the decreasing number and ratio of Eastern Slavs led to stagnation or even increased ethnic diversity. Although, e.g. in Riga, the ratio of Latvians grew by 6 percentage points between 1989 and 2009, the EDI increased during the same period.

\section{Results - ESI at country level}

The Ethnic Segregation Index is definable by ethnic groups and - in conformity with the logic of the method - it is expedient to calculate at country level from ethnic data of the municipalities. By means of the ESI we are able to find out the exact value of the spatial isolation of a certain ethnic group, in other words to what extent it is segregated from the other ones. The higher the degree of the ESI is, the easier a compact ethnic block - with sharper ethnic boundaries - is definable.

Figure 10 proves that in Latvia traditionally did not exist and during the $20^{\text {th }}$ century did not come into existence compact ethnic blocks. The ethnic groups lived in the country always mixed; the most typical feature of their distribution was the spatial 'dispersion'. The only exceptions were the Belarusians who concentrated after the WWI in a well definable zone, south from the Zilupe - Ilūkste line.

During the first independence period the Russians' ESI value stagnated while in the cases of other ethnic groups it slightly decreased. Nevertheless, the significant decline of the Belarusians' segregation index is conspicuous. The official number of the Belarusians decreased by $1 / 3$ between 1925 and 1935, however on the basis of migration and natural reproduction data, it can be stated that none of it explains such a serious alteration; there must have been political reasons too. Namely a remarkable ratio of the people who previously declared themselves as Belarusians, in 1935 chose another (particularly Latvian or even Russian) ethnicity. ${ }^{24}$ This tendency was typical especially in Latgale, thus while the relative weight of

24 The question of assimilation process during the Ulmanis regime was mentioned in chapter 4.1 . 
the Belarusian ethnic block in South-Latgale decreased, the relative weight of other Belarusian communities in Latvia increased. On the whole the spatial segregation of the Belarusians within Latvia - according to the official data - declined significantly.

In contrast to the interwar period a more serious alteration came about during the years of the Soviet occupation: the degree of Ethnic Segregation Index dropped significantly in all cases. Although neither Marx nor Engels or Lenin envisaged a "world in which there would be no role for nations" 25 , in the Russian-dominated Soviet Union the official policy towards the national identity was rather dismissive. Instead of this "despised reactionary phenomenon" the ideologists propagandized the emergence of a new historical community, the 'Soviet people' - "sharing a common territory, economic system, culture, the goal of building communism and a common langue". ${ }^{26}$ In order to achieve this unity one of the tools might be the abolition of traditional ethnic structures through Russification, in other words - from a geographer point of view - through reducing spatial segregation of the ethnic groups. This endeavour might have a noticeable consequence for ESI values of certain ethnic groups not only within the Soviet Union but also within the Latvian SSR (Figure 10). The big industrial cities functioning as melting pots attracted most of the immigrants from the other parts of the Soviet Union as well as from the Latvian countryside, thus the traditional ethnic map of Latvia changed drastically. Little wonder that in 1989 the most urbanised ethnic groups (the Ukrainians and the Belarusians) were the less segregated ones, while the ESI values of the Latvians and Lithuanians - whose ethnic territory changed in the lowest degree - decreased just a little during the Soviet occupation period.

During the first decade of the second independence period the Ethnic Segregation Indexes did not changed significantly, thus the real tendency will become obvious only by right of the 2011 census data (Figure 10).

\footnotetext{
${ }^{25}$ G. Smith, The Nationalities Question in the Soviet Union (Longman, London and New York, 1990), 1-4

26Ibid., 9
} 
Figure 10. Alteration of Ethnic Segregation Index of certain ethnic groups in Latvia. Tested at municipal level

\begin{tabular}{|c|c|c|c|c|c|}
\hline \multirow{7}{*}{ 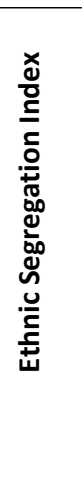 } & 90,00 & \multirow[b]{2}{*}{$\Delta$} & & & \\
\hline & 80,00 & & & & \\
\hline & 60,00 & & & & \\
\hline & 40,00 & & & & \\
\hline & 30,00 & & & & $x$ \\
\hline & 20,00 & & & & \\
\hline & 10,00 & 1925 & 1935 & 1989 & 2000 \\
\hline$\square$ & Germans & 63,53 & 61,77 & 0,00 & 0,00 \\
\hline 0 & Jews & 64,43 & 61,64 & 0,00 & 0,00 \\
\hline$\diamond$ & Ukrainians & 0,00 & 0,00 & 24,40 & 27,73 \\
\hline$\cdots-$ & - Estonians & 61,30 & 59,34 & 29,72 & 32,33 \\
\hline$x$ & - Lithuanians & 57,39 & 52,98 & 39,20 & 40,18 \\
\hline$-\diamond$ & Poles & 53,37 & 45,86 & 34,74 & 35,90 \\
\hline$\Delta$ & - Belarusians & 81,69 & 46,63 & 22,21 & 24,02 \\
\hline$\square$ & - Russians & 59,09 & 59,58 & 34,66 & 36,99 \\
\hline$\rightarrow$ & - Latvians & 53,14 & 46,94 & 38,77 & 40,22 \\
\hline
\end{tabular}

Edited by the authors

\section{Conclusions}

The results of the research revealed that Latvia has one of the most diverse population in our continent: in 2009 Ethnic Segregation Index was higher only in three other European countries. The change in the EDI showed a characteristic wave during the 20 th century: its degree dropped until World War II, then rose steadily until 1989 and then, after the restoration of independence, it shows a downward trend again. According to the aims of this study especially the data from the period 1925-1935 and 1989-2009 were relevant. It is very interesting that during the first and second independence period a very similar ethnic homogenization occurred in Latvia; however the most important goal of this study was the analysis of the spatial processes.

Although the diversity map of Latvia has changed a lot since the WWI, three basic features have been still dominating: the cities/towns- 
countryside, Riga-Latvia and the east-west dichotomy. In other words while the countryside was always ethnically more or less homogeneous, Riga, the other towns and Latgale had always very high degree of ethnic heterogenenity. However, the components of society have been exchanged; the historical minorities (Jews, Germans) almost disappeared, whereas the number and ratio of Eastern Slavic people considerably increased.

In Latvia traditionally did not exist and during the 20th century did not come into existence compact ethnic blocks. The ethnic groups lived in the country always mixed; the most typical feature of their distribution was the spatial 'dispersion'. The segregation indexes of the ethnic groups tested at municipal level - changed relatively slightly during the first and second independence periods. In contrast with this tendency alteration of ESI was rather significant during the Soviet occupation.

The study examined the alteration of the ethnic composition of Latvia in the first and second independence periods using calculation methods which are still not very widespread in human geography. However, the research is far from being complete, as the results of the 2011 census will soon be disclosed. 


\section{References:}

Aasland, A. Ethnicity and Poverty. Riga: Social Policy Research Series. Fafo Institute for Applied Social Science. Ministry of Welfare of the Republic of Latvia. UN Development Programme, 2000, 52 p.

Bajmócy, P. 'Magyarország népességének etnikai és vallási diverzitása 1910-ben és 2001-ben.'In Táj, környezet és társadalom. Eds. A. Kiss, et al. Szeged: SZTE Éghajlattani és Tájföldrajzi Tanszék és SZTE Természeti Földrajzi és Geoinformatikai Tanszék, 2006, 57-68.

Bajmócy, P. Általános etnikai és vallás földrajz. Szeged: JATE Press, 2009, 117 p.

Bērziņš, A.' Iedzīvotāju etniskā sastāv aizmaiņu raksturojums.' In Demogrāfiskā attīstība Latvijā 21.gadsimta sākumā.Riga: Zinātne, Nr. 3(9), 2006, $136 \mathrm{p}$.

Bojtár, E. Bevezetés a baltisztikába. Budapest: Osiris, 1997, 316 p. [in English: Bojtár, E. Foreword to the Past: A Cultural History of the Baltic People. Budapest: CEU Press, 1999, 419 p.]

Greenberg, J. H. 'The Measurement of Linguistic Diversity.' Language. Vol. 32, 1 (January - March 1956): 109-115.

Győri Sz. R. 'Autonómia a posztszovjet, európai utódállamokban.' Kisebbségkutatás 2 (2006). Available at:

http://www.hhrf.org/kisebbsegkutatas/kk_2006_02/cikk.php?id= $\underline{1366}$, accessed at 28 July 2011.

Ham, M. van and T. Tammaru. 'Ethnic Minority - Majority Unions in Estonia.' European Journal of Population. Vol. 27, 3 (August 2011): 313-335.

http://www.ncbi.nlm.nih.gov/pmc/articles/PMC3163815/

Ivanov, A. 'Historiography as Framing and Support Factor of Ethnic Identity: the Case of Historiography of Latgale.' In V. Volkov Ethnicity. Politics of Recognition. Daugavpils: vol. 2, 1, 2010.

Krišjāne, Zaiga et al.' Changing Patterns of Population Mobility in Latvia.' In Marking Latvia's Return to Europe, ed. À. Krauklis. Rīga: Ģeogrāfiski Raksti, XII. Latvijas Ģeogrāfijas biedrība, 2004, 65-73.

Krisjane, Zaiga and Andris Bauls, 'Regional features of migraton in Latvia.' In Demographic situation: present and future. Ed. P. Zvidrinș. Riga: Research papers, Strategïskās analizes komisija, 4 (8), 2006.

Lagzi, G. Kisebbségi kérdés, nemzeti kisebbségek Észtországban, Lettországban és Litvániában a rendszerváltást követő időszakban. Budapest: 
Európai Összehasonlító Kisebbségkutatások Közalapítvány, Múhelytanulmány 33, 2008, 65 p.

Meyer, P. and P. Overberg. 'Updating the USA TODAY Diversity Index' (2001). Available at: http://www.unc.edu/ pmeyer/carstat/tools.html. Accessed at 28 July 2011.

Mežs, I. Latvieši Latvijā. Etnodemogräfisks apskats. Riga: Latvijas vēstures institūta, etnogrāfiskas nodaļa, Zinātne, 1994a.

Mežs, I. 'The Ethno-Demographic Status of the Baltic States,' GeoJournal. Vol. 33, 1 (1994b): 9-25.

Mežs, I.The Latvian Language in the Mirror of Statistics. Jāña sēta Map Publishers, 2005.

Németh, Á. 'Von der Reichsmajorität zur marginalen Minderheit: die "Russische Frage” im sozialistischen und nachwendezeitlichen Baltikum.' In Minderheitendasein in Mittel- und Osteuropa - interdisziplinär betrachtet. Eds. GernerZs. and L. Kupa. Hamburg: Verlag Dr. Kovač, Socialia - Studienreihe Soziologische Forschungsergebnisse, Band 133, 2011, pp. 89-102.

Rauch, G., R. J. Misiunas, and R. Taagepera A balti államok története (Budapest: Osiris-Századvég - 2000, 1994, 467 p.)

Ray, B. 'A Description of the Ethnic Segregation/Mixing within Major Canadian Metropolitan Areas Project.' University of Ottawa, 2008, 23 p. http://www.cic.gc.ca/english/pdf/research-stats/ethnicsegregation.pdf)

Reményi, P. 'Etnikai homogenizáció a volt Jugoszláviában. 'In Magyarország és a Balkán - Balkán füzetek, Különszám I, Zs. M. Császár. Pécs, 2009, 122-129.

Simpson, E. H. 'Measurement of Diversity,' Nature 163 (1949): 688.

Smith, G., ed. The Nationalities Question in the Soviet Union. London and New York: Longman, $380 \mathrm{p}$.

Strods, H. Latgales iedzīvotāju etniskais sastāvs 1772-1959. Riga: P. Stučkas Valsts Universitāte, Vēstures un Filozofijas Fakultāte, 1989.

Strömgren, $\mathrm{M}$ et al. 'Pre-Hire Factors and Workplace Ethnic Segregation,' IZA Discussion Paper, No. 5622 (April 2011).

http:/ / papers.ssrn.com/sol3/papers.cfm?abstract_id=1812467

Vìtolinšs, E. and P. Zvidrinsš. 'The Demographic Situation in Latvia at the Beginning of the 21 th Century.' In Demographic Development in Latvia. Ed. 
V. Ivbulis. Riga: University of Latvia, Humanities and Social Sciences, 2(35)/2002, 5-32.

Krišjāne, Z. et al. (2004) 'Changing Patterns of Population Mobility in Latvia,' in Krauklis, Ā. (ed.) (2004) Marking Latvia's Return to Europe (Ģeogrāfiski Raksti, XII. Latvijas Ģeogrāfijas biedrība, Rīga), pp. 65-73.

Zeile, P. 'Latgaliešu etnomentālitāte un kultūra.' Acta Latgalica, Daugavpils, 9 (1997): 273-299.

Zvidriņš, P. and I. Vanovska. Latvieši. Statistiski demogräfisks portretējums. Riga: Zinātne, 1992, 165 p.

Zvidrinšs, P.' Changes of the Ethnic Composition in the Baltic States,' Nationalities Papers, vol. 22, 2(1994): 365-377.

Zvidrinsš, P.Depopulācija Latuijāa (Riga: LU Akadēmiskaisapgāds, 2010, 60 p.)

1925. gada, Otrā tautasskaitī̌̌ana Latuijā. Valsts Statistikā Pārvalde. Ed. M. Skujenieks. Riga, 1925.gadā.

1935. gada, Ceturtā tautasskaitīšana Latvijā. Iedzīotāju skaits, dzimums un pavastniecỉba.Valsts Statistikā Pārvalde. Eds. V. Salnītis and M. Skujenieks. Riga, 1936.gadā.

1989. gada vissavienības tautasskaistī̌̌anas rezultāti. Latvijas PSR (demogrāfiskierādītāji). Latvijas PSR Valsts Statistikas Komiteja. Riga, 1990.

1989. gada tautasskaitī̌̌anas rezultāti Latvijā. Latvijas Republikas Valsts Statistikas Komiteja, Statistiku datu krājums. Riga, 1992.

Latvijas 2000. gada tautasskaitī̌̌anas rezultāti (CD-ROM). Latvijas Statistika, 2002.

http://www.csb.gov.lv/dati/statistikas-datubazes-28270.html-0 